\title{
Implementation of Islamic Spiritual Guidance for People with Mental Disorders at the Jalma Sehat Kudus Foundation
}

\author{
Hasan Bastomi \\ Institut Agama Islam Negeri Kudus, Indonesia \\ hasan@iainkudus.ac.id
}

\begin{abstract}
Implementation of Islamic Spiritual Guidance for People with Mental Disorders at the Jalma Sehat Kudus Foundation. This study aims to reveal the implementation of Islamic spiritual guidance for people with mental disorders at the Jalma Sehat Kudus Foundation. This research on the implementation of Islamic spiritual guidance for people with mental disorders was carried out using a qualitative approach with the type of field research (field research) with data collection techniques using Interview, Observation and Documentation. The research subjects or informants in this research are the Chairperson of the Jalma Sehat Kudus Foundation, nurses, and spiritual mentors of the Jalma Sehat Kudus Foundation. The results showed that the Jalma Sehat Kudus Foundation in carrying out spiritual guidance for people with mental disorders. Methods. Spiritual guidance for people with mental disorders was carried out by the individual method (direct) and the group guidance method. The stages and materials for spiritual guidance for people with mental disorders are in three stages, namely: (1) the initial stage is by introducing Fiqh Worship, (2) the intermediate stage is the seriousness stage, namely by providing religious lecture guidance, and the final stage is the stage of ending the guidance process ( termination). Suggestion It is necessary to have a permanent spiritual guide who is assigned to carry out spiritual guidance at the Jalma Sehat Kudus Foundation so that the implementation of Islamic spiritual guidance can run continuously.
\end{abstract}

Keywords: Guidance, Islamic Spirituality, Mental Disorders 


\section{A. Introduction}

Mental disorders are clinically significant syndromes or behavioral patterns that are associated with distress or suffering and cause disturbances in one or more functions of human life. (Keliat, 2011: 123). The phenomenon of mental disorders is currently experiencing a very significant increase, and every year in various parts of the world the number of people with mental disorders increases. Based on data from the World Health Organization (WHO) in Yosep (2013: 23), There are about 450 million people in the world who suffer from mental disorders. WHO states that at least one in four people in the world experience mental problems, and the problem of mental health disorders that exist throughout the world has become a very serious problem.

Based on the results of research from Rudi Maslim in Mubarak (2011: 89) The prevalence of mental health problems in Indonesia is 6.55\%. This figure is moderate compared to other countries. Data from 33 Mental Hospitals (RSJ) throughout Indonesia states that up to now the number of people with severe mental disorders has reached 2.5 million people.

Patients with severe mental disorders aged over 15 years in Indonesia reached $0.46 \%$. This means that there are more than 1 million people in Indonesia who suffer from severe mental disorders. Based on these data, it is known that $11.6 \%$ of the Indonesian population has mental and emotional problems (Departemen Kesehatan RI, 2007: 67). Meanwhile, in 2013 the number of people with mental disorders reached 1.7 million (Departemen Kesehatan RI, 2013: 87).

The prevalence of severe mental disorders or in medical terms called psychosis/schizophrenia in rural areas is actually higher than in urban areas. In rural areas, the proportion of households with at least one household member experiencing severe mental disorders and having been in pasung reached 18.2 percent. Meanwhile in urban areas, the proportion only reached 10.7 percent. This seems to confirm that the life pressures experienced by rural residents are heavier 
than urban residents. And it's easy to predict, one of the stresses of life, though not always economic hardship (Departemen Kesehatan RI, 2013: 88)

The prevalence of mental disorders in Central Java reaches 3.3\% of the entire population (Balitbangkes, 2008: 56). Based on data from the Central Java Provincial Health Office, there were 1,091 cases of mental disorders and some of these cases were living in shackles. This figure was obtained from data collection from January to November 2012. Based on the number of visits by people with mental disorders to health services, both puskesmas, hospitals, and other health care facilities, in 2009 there were 1.3 million people who visited, it is estimated that as many as $4.09 \%$ (Herusanson, 2012).

Developments that continue to advance have resulted in increasingly complex human needs and various problems faced in various fields of life. So peace of mind is the first capital that must be owned by everyone who longs for the happiness of life (Daradjat, 1985: 12). With the development of psychology (psychology), it is known that humans need help to overcome the difficulties they face and various psychiatric services have emerged, from the lightest (guidance), moderate (counseling), and the most severe (therapy). And psychology developed so that it has applied branches, including guidance, counseling and therapy. Furthermore, it was found that religion, especially Islam has the functions of guidance, counseling, and therapy services where the philosophy is based on the verses of the Qur'an and the Sunnah of the Prophet.

Religion cannot be separated from human life. Human denial of religion may be due to certain factors, both caused by their respective personalities and environments, but to cover up or completely eliminate religious impulses and feelings seems difficult to do, this is because humans have an inner element that tends to encourage them to submit to substances. the unseen. This submission is part of the internal human factor which in personality psychology is called the person (self) or conscience (conscience of man). 
Religion as human nature has been informed by the Quran. Human nature as a creature created by Allah SWT is that humans are created to have religious instincts, namely the religion of monotheism. If there are people who do not believe in monotheism, then it is not natural, they do not believe in monotheism only because of environmental influences, as stated in QS. Ar Rum: 30-31(Jalaludin, 2010: 165).

The relationship between religion as a belief and mental health lies in the attitude of one's surrender to a supreme power. This attitude will give a person an optimistic attitude so that positive feelings arise such as feeling happy, satisfied, successful, feeling loved, or feeling safe. Such an emotional attitude is part of the need for human rights as creatures who believe in God. So in these conditions humans are in a calm and normal state (Bastomi, 2017).

Islamic spiritual guidance is an effort to provide assistance to someone who is experiencing difficulties, both outwardly and inwardly, concerning life in the present and in the future. The assistance is in the form of help in the mental and spiritual fields, with the intention that the person concerned is able to overcome his difficulties with the abilities that exist in himself, through the strength of faith and piety (Arifin, 1982: 2).

The soul and the physical body must be properly maintained so that the balance is not disturbed, if the balance of the two is disturbed then the next thing is the stage when the repair process must be carried out, such as healing carried out in a mental hospital for people with mental disorders, everything must be considered early on by doing the following things: positive things that can increase the productivity of life (Massuhartono \& Mulyanti, 2018).

As the Jalma Sehat Kudus Foundation has done in helping people with mental disorders so that they can regain their mental health. According to Heru Sutiyono, the owner of the Jalma Sehat Kudus Foundation, people with mental disorders are not a rarity in villages or in metropolitan cities, the number is currently out of control. People tend to be indifferent, even speed up the steps to 
avoid physical contact with people with mental disorders, it seems that there is very little sympathy for people with mental disorders, even though it is the responsibility of caring for people with mental disorders and making people with mental disorders to live decently and even recover from their illness. together with the Jalma Sehat Kudus Foundation.

Based on a pre-research conducted by researchers at Jalma Sehat, it is a simple shelter, people with mental disorders who originally lived chaotic lives were given a better opportunity to enjoy their days. Sleeping in the room, eating regularly, bathing, being treated, working with farming activities and getting spiritual guidance through various therapies. Therefore, the study in this research is the implementation of spiritual guidance for people with mental disorders at the Jalma Sehat Kudus Foundation.

\section{B. Metode}

Research on the implementation of spiritual guidance for people with mental disorders at the Jalma Sehat Kudus Foundation was carried out using a qualitative approach with the type of field research (field research) with data collection techniques using Interview, Observation and Documentation Techniques. The research subjects or informants in this research are the Chairperson of the Jalma Sehat Kudus Foundation, nurses, and spiritual mentors of the Jalma Sehat Kudus Foundation. Then the data collected was analyzed by qualitative descriptive analysis technique which consists of three stages, namely: first, the Data Reduction stage, which is the process of classifying and categorizing the data found in research on the implementation of spiritual guidance for people with mental disorders at the Jalma Sehat Foundation. Holy. Second, the data presentation stage (Display Data), which is a checking technique in the research process that is used to make it easier for researchers to make data into a social picture in the form of words, as well as to correct the existing da ta unity from the results of research conducted (Sugiyono, 2014: 343) regarding the implementation of spiritual guidance for people with mental disorders at the Jalma Sehat Kudus 
Foundation. Third, the conclusion and verification stage is a step to draw the main points and truths about the implementation of spiritual guidance for people with mental disorders at the Jalma Sehat Kudus Foundation.

\section{Discussion}

\section{Islamic Spiritual Guidance}

Guidance is literally a translation taken from English, namely "guidance" which comes from the verb toguide, which means to guide, to guide, to guide the way, and to drive. The broader understanding of guidance is assistance given to individuals so that with their potential they are able to develop themselves optimally by understanding themselves, understanding the environment, overcoming obstacles in order to determine better future plans.

Guidance is a process of providing assistance by experts to a person or several individuals, both children, adolescents, and adults, so that the person being guided can develop their own and independent abilities by utilizing individual strengths and existing facilities and can be developed based on norms. applicable norms (Deliani, 2019).

The word guidance in Indonesian provides two basic meanings, First, to provide information, which is to provide knowledge that can be used to make decisions, or to give something by giving advice. Second, directing, leading to a goal. A goal known only to the person directing and asking for direction (Siradj, 2012: 5). To find out more about the meaning of guidance in general, here are the opinions of the experts:

1) According to Dunsmorr \& Miller in Mc Daniel, guidance is a service process provided to individuals to help them acquire the knowledge and skills needed to make the choices, plans and interpretations needed for good adjustment. (Luddin, 2010: 14).

2) Crow \& Crow, that guidance is assistance given by a man or woman, who has adequate personality and is well trained to individuals of every age to help him 
organize his own life activities, develop his own outlook on life, make his own decisions and bear his own burdens (Prayitno \& Amti, 2013: 94).

3) Bimo Walgito stated that guidance is assistance or assistance given to individuals in avoiding or overcoming difficulties in their lives, so that individuals or groups of individuals can achieve their welfare. (Mu'awanah \& Hidayah, 2012: 54).

Spirituality is a part of the body that is very difficult to describe, but if the author defines spiritual or spirit, then the spirit is an important aspect in the continuity of human life without which humans cannot live or move. The meaning of Islam comes from the Arabic language which means safe, peaceful, and peaceful. From the word salima changed to the form aslama which means surrender. Thus, the meaning of Islam is surrender, safety, and peace (Asy, ari \& Hamim, 2008: 2). Islamic teachings are sourced from the Qur'an and Hadith, both of which in practice must be conveyed or preached to all humans in order to achieve the goals of the understanding of Islam itself.

Spiritual Islam according to Adz-Dzaky is defined as an activity of providing guidance, lessons, and guidelines to individuals who ask for help in terms of what a client should be able to develop the potential of mind, psyche, faith, and belief, and be able to cope with the problems of life properly and correctly. independently based on the Qur'an and Sunnah.

According to Bukhori, Islamic spiritual guidance is a service that provides spiritual compensation to patients and their families in the form of providing motivation to be steadfast and patient in facing trials, by providing guidance on prayer, how to cleanse, pray and practice worship performed in a sick state. (Saputra, 2015).

So Islamic spiritual guidance is the process of providing assistance to individuals in the form of information, plans, and actions through oral and written sources from the Qur'an and hadith in overcoming difficulties encountered related 
to individual spirituality, in order to get a feeling of patience in dealing with problems that lead to spiritual problems. individual safety and peace.

Islamic spiritual guidance is an activity in which there is a process of spiritual guidance and guidance to clients as an effort to perfect medical and spiritual endeavors. The guidance process is carried out as an effort to motivate people to remain patient, put their trust in, and always carry out their obligations as servants of Allah SWT (Thohir, 2008: 6).

In accordance with the concept that was brought, namely Islam, and Islam originated from the Qur'an and al-Sunnah (Asy'ari \& Hamim, 2008: 7). So the implementation of Islamic spiritual guidance is based on the Qur'an and al-Sunnah / Hadith of the Prophet SAW. The basis of the Qur'an al-Sunnah / Hadith of the Prophet SAW regarding Islamic spiritual guidance is as follows, which means: "And help you in (doing) virtue and piety, and do not help in committing sins and transgressions. . and fear Allah, verily Allah is severe in punishment." (QS: al-Maidah ayat 2) (Kemenag RI, 2013: 320). In addition, it is also contained in QS: Yunus ayat 57 yang artinya: " O mankind, indeed there has come to you a lesson from your Lord and a cure for the diseases (which are) in the chest and guidance and mercy for those who believe.." (QS: Yunus ayat 57).

From the two holy verses of the Qur'an and one hadith of the Prophet above, it is explained that we fellow human beings, especially fellow Muslims, must help each other in virtues such as curing disease in a good way like Islamic spiritual guidance which provides assistance to sick people with one of the following methods: The way is to pray to Allah SWT for health and healing in the world and the hereafter as inner peace.

The functions of Islamic spiritual guidance are as follows: (1) preventive function, which is to help individuals maintain or prevent problems from arising for themselves, (2) curative or corrective functions, namely assisting individuals in solving problems that are being faced or experienced. (3) Preservative function, which is helping individuals to keep situations and conditions that were originally 
not good (containing problems) to be good (solved) and goodness lasts a long time (in state of good). (4) The function of development or development, which is to help individuals maintain and develop situations and conditions that have been good so that they remain good or become better, so that they do not allow them to be the cause of problems for them (Salamah, 2018).

Islamic spiritual guidance has methods and techniques, the method can be interpreted as a way to approach the problem so that satisfactory results are obtained, while the technique is the implementation of the method in practice. The direct Islamic spiritual guidance method is a method in which the mentor communicates directly with the person he is guiding, this method can be further detailed, namely individually and in groups. Individualized method in which the spiritual officer provides direct guidance to the patient one by one. The techniques used are conversations, home visits, and work observations (Saputra, 2015).

\section{Mental Disorders}

Mental disorders are manifestations of behavioral deviations due to emotional distortion so that irregularities are found in terms of behavior. This happens because of the decline in all mental functions (Buddu Anna Keliat, Akemat, \& Heni, 2011: 47). Meanwhile, according to the Law of the Republic of Indonesia No. 18 of 2014, people with mental disorders, abbreviated as ODGJ, are people who experience disturbances in thoughts, behavior, and feelings that are manifested in the form of a set of symptoms and significant behavioral changes, and can cause suffering and obstacles in carrying out people's functions as human beings (Law No. 18 years).

Mental disorders are psychological or behavioral patterns shown in individuals that cause distress, reduce quality of life and dysfunction. It reflects psychological dysfunction, not as a result of social deviation or conflict with society (Stuart \& Sundeen, 2013: 93). Meanwhile, according to Keliat (2011: 87), Mental disorders are behavioral patterns, clinically significant syndromes associated with suffering, distress and causing impairment in more or one function of human life. 
According to Videbeck in Nasir (2011: 125) said that the general criteria for disorders are as follows: (a) Dissatisfied with living in the world. (b) Dissatisfaction with the characteristics, abilities and self-achievement. (c) Unaffective coping with life events. (d) There is no personal growth. According to Keliat et al., in Prabowo, (2014: 156) said there are also characteristics of mental disorders that can be identified as follows: (a) Self-isolation. (b) Don't know other people. (c) Angry for no reason. (d) Disorganized speech. (e) Unable to take care of themselves.

Things that can affect human behavior are heredity and constitution, age and gender, physical condition, psychological state, family, customs, culture and beliefs, work, marriage and pregnancy, loss and death of loved ones, aggression, feelings of hostility, human relations and so on. Although the general symptoms or symptoms that meninjil contained in the psychological element, but the main cause may be in the body (somatogenic), in the social environment (sociogenic), or dipsike (psychogenic). Some of these causes occur together, then a body or mental disorder arises (Yosep, 2013: 203). On the other hand, a person with a physical illness, when experiencing weakness, decreases his psychological endurance so he may experience depression, because it is modernly known that diseases of the brain often cause mental disorders.

According to Yosep (2013: 204) The source of the cause of mental disorders is influenced by factors in the three elements that continuously influence each other, namely: (1) Somatic or organobiological factors, namely: (a) Neroanatomy, (b) Nerophysiological, (c) Nerochemistry, (d) Level maturity and organic development, (e) pre and peri-natal factors (2) Psychological factors, namely: (a) Mother-child interaction and the role of fathers, (b) Competition between siblings, (c) Intelligence, (d) Relationships in family, work, play and society, (e) Loss, selfconcept, adaptation patterns, (f) Level of emotional development (3) Socio-cultural or sociocultural factors, namely: (a) family stability, (b) Parenting patterns (c) Economic level, (d) Housing, urban versus rural. 


\section{Islamic Spiritual Guidance at the Jalma Sehat Kudus Foundation}

a. Methods of Spiritual Guidance for People with Mental Disorders at the Jalma Sehat Kudus Foundation

Methods Spiritual guidance for people with mental disorders is carried out by the individual method (direct) and the group guidance method. Both individual and group methods. The technique is by providing information, often referred to as the lecture method, namely giving an explanation from a speaker to an individual or group (Salim, 2021).

b. Stages and Materials of Spiritual Guidance for People with Mental Disorders at the Jalma Sehat Kudus Foundation

The provision of spiritual guidance to people with mental disorders at the Jalma Sehat Kudus Foundation is based on four phases. The first phase is for patients who are entering Jalma Sehat for the first time from the results of the Stapol PP raids, submissions from the Social Service and community submissions. The patient will be starved first, then his body will be cleaned and taught to maintain body hygiene, given proper clothing and then given food or taught to eat and put psychiatric drugs through food that has been consulted with a psychiatrist adjusted to the level of his mental disorder then placed in a cell. The second phase, namely by getting people with mental disorders to be able to maintain body hygiene, wear proper clothes and eat regularly and still be placed in cells. The third phase, namely people with mental disorders whose recovery rate is more than $50 \%$ are allowed to be placed outside the cell, while still being given lessons related to maintaining body hygiene, dressing and eating regularly and other healthy lifestyles.

The fourth phase, intended for people with mental disorders who have a cure rate of around $80 \%$, these patients are allowed to be placed outside the cell and employed or given jobs whose placements are arranged by the Jalma Sehat Kudus Foundation in collaboration with 
foundation partners, such as building work, guarding parking, working in the workshop, being a Laundry employee to becoming a Hotel/Wisma Waiter and every day people with mental disorders go to work. The patient is still under surveillance regarding his mental state, because there is still the possibility of relapse.

These phases are also related to spiritual guidance services provided to people with mental disorders. Spiritual Guidance is only intended for people with Mental Disorders who experience a cure rate of $80 \%$. This is because the mental disorder sufferers are considered mentally stable, so it is safe to be placed outside and participate in spiritual guidance services. In addition, spiritual guidance is also a preventive effort so that people with mental disorders remain mentally stable and do not relapse. Because it is recognized by the Management, religious advisors and nurses, that people with mental disorders who diligently participate in spiritual guidance activities have more stable souls and rarely relapse. In contrast to people with mental disorders who are lazy to follow spiritual guidance, it is easier to relapse. People with mental disorders who relapse will be placed in cells, because it is feared that they will interfere with the safety and security of the Jalma Sehat Foundation (Ristiani, 2021).

The stages and materials for spiritual guidance for people with mental disorders are in three stages, namely: the initial stage, the intermediate stage, and the final stage, namely:

1) The initial stages are teaching and introduction to Fiqh of Worship and religious guidance. At this stage, people with mental disorders are given teaching related to the following materials:

a) Thaharoh, namely by teaching people with mental disorders to perform ablution before praying and bathing in Junub when having big hadas. 
b) Guidance in calling the Adhan before carrying out the Fardhu Prayer. This guidance can make people with mental disorders called and enthusiastic to pray. In addition, it also trains the selfconfidence of people with mental disorders when they dare to say the Adhan in front of spiritual guides and fellow people with mental disorders.

c) Prayer in congregation, as it is known that prayer can raise full awareness of self-identity which acts as a healthy mental attitude, especially when carried out in congregation it will increase enthusiasm because there is social interaction between people with mental disorders.

d) Guiding the reading of Dhikr and Shalawat, after the prayer activities. In the Qur'an it is explained that with remembrance the heart becomes calm

e) Praying after prayer and dhikr, sick patients need mental encouragement. This prayer guidance will help people with mental disorders have mental encouragement and put their trust in Allah SWT. This is another side of need that should not be ignored.

2) The intermediate stage, the seriousness stage, namely by providing religious lecture guidance for people with mental disorders.

Guidance of religious lectures for people with mental disorders, the theme presented in religious lectures. The first material presented was about the Oneness of Allah and the importance of remembering Allah. This is done because most people with mental disorders forget the spiritual aspect (God). After that, it is continued with the theme of commendable attitudes, for example about the importance of being grateful, the importance of remembering Allah, being patient, Qona'ah (receiving God's gifts), staying away from envy, staying away from despicable behavior, being a person who is 
not easily angry, etc. With the guidance of the religious lecture, it is hoped that it can be a reminder for people with mental disorders to always carry out Allah's commands and stay away from His prohibitions. In addition, people with mental disorders are also given material about relationships between humans (hablum minan nas), for example, smiling when meeting people, being friendly with greetings because smiling is charity, then helping or helping friends who are in trouble so that this will create a sense of empathy between fellow sufferers. mental disorders.

3) The final stage, ending the guidance process

The process can end if the goal has been achieved, but can also end if the person with mental disorders cannot continue the process. Likewise, a mentor can end his mentoring process. By ending the Islamic guidance process that the patient must be notified in advance. This is important because people with mental disorders after this will face a new environment alone without any mentor. And his dependence on the current supervisor must be immediately eliminated by growing the independence of people with mental disorders. For that, everything needs to be prepared well, and carefully in advance (Salim, 2021).

\section{Conclusion}

The Jalma Sehat Kudus Foundation in carrying out spiritual guidance for People with Mental Disorders Method Spiritual guidance for people with mental disorders is carried out by the individual method (direct) and the group guidance method. The stages and materials for spiritual guidance for people with mental disorders are in three stages, namely: (1) the initial stage is by introducing Fiqh Worship, (2) the intermediate stage is the seriousness stage, namely by providing religious lecture guidance, and the final stage is the stage of ending the guidance process ( termination). Suggestion It is necessary to have a permanent spiritual 
guide who is assigned to carry out spiritual guidance at the Jalma Sehat Kudus Foundation so that the implementation of Islamic spiritual guidance can run continuously. 


\section{REFERENCES}

Arifin. (1982). Bimbingan dan Konseling. Jakarta: Bina Aksara.

Asy'ari, A. M., \& Hamim, N. (2008). Pengantar Studi Islam. Surabaya: IAIN Sunan Ampel Press.

Balitbangkes. (2008). Riset Kesehatan Dasar 2007, Laporan Nasional. Jakarta: Balitbangkes Depkes RI.

Bastomi, H. (2017). Menuju Bimbingan Konseling Islami. KONSELING EDUKASI: Journal Of guidance And Counseling, 1 No. 1.

Daradjat, Z. (1985). Pembinaan Jiwa Mental. Jakarta: Bulan Bintang.

Deliani, D. (2019). Implementasi Bimbingan Rohani Islam Dalam Memotivasi Ghirah Agama Bagi Korban Penyalahgunaan Narkotika Di Institusi Penerima Wajib Lapor (LPWL) Bukit Doa Taman Getsemane. Universitas Islam Negeri Sumatera Utara Medan.

Departemen Kesehatan RI. (2007). Riset Kesehatan Dasar. Jakarta: Badan Penelitian dan Pengembangan Kesehatan, Departemen Kesehatan RI.

Departemen Kesehatan RI. (2013). Riset Kesehatan Dasar. Jakarta: Badan Penelitian dan Pengembangan Kesehatan, Departemen Kesehatan RI.

Herusanson, W. (2012). Penderita gangguan jiwa di Jawa Tengah banyak dilakukan pemasungan. Kompas.com. Retrieved from https://edukasi.kompas.com/read/2012/08/29/09544270/ Regional Jawa

Jalaludin. (2010). Psikologi Agama. Jakarta: Raja Grafindo Persada.

Keliat, Buddu Anna, Akemat, H. N., \& Heni, N. (2011). Keperawatan Kesehatan Jiwa Komunitas CMHN (Basic Course). Jakarta: EGC.

Keliat, Budu Anna. (2011). Keperawatan Kesehatan Jiwa Komunitas. Jakarta: EGC.

Kemenag RI. (2013). Al Qur'an dan Terjemahnya. Semarang: Toha Putra.

Luddin, A. B. M. (2010). Dasar-Dasar Konseling Tinjauan Teori Dan Praktik. Bandung: Ciptapustaka Media Perintis.

Massuhartono, \& Mulyanti. (2018). Terapi Religi Melalui Dzikir Pada Penderita Gangguan Jiwa. Journal of Islamic Guidance and Counseling, 2 No. 2, 201-214.

Mu'awanah, E., \& Hidayah, R. (2012). Bimbingan Konseling Islami Di Sekolah Dasar. Bandung: Bumi Aksara. 
Mubarak, I. . (2011). Promosi Kesehatan Masyarakat untuk Kebidanan. Jakarta: Salemba Medika.

Nasir, A., \& Muhith, A. (2011). Dasar-dasar Keperawatan jiwa, Pengantar dan Teori. Jakarta: Salemba Medika.

Prabowo, E. (2014). Konsep Dan Aplikasi Asuhan Keperawatan Jiwa. Yogyakarta: Nuha Medika.

Prayitno, \& Amti, E. (2013). Dasar-Dasar Bimbingan Dan Konseling. Jakarta: Rineka Cipta.

Salamah, U. (2018). Bimbingan Rohani Islam Melalui Metode Dzikir Pada Loneliness Lanjut Usia (Lansia) Di Griya Palang Merah Indonesia (PMI) Kota Surakarta. IAIN Surakarta.

Saputra, R. (2015). Pengaruh Intensitas Mengikuti Bimbingan Agama Islam Terhadap Kesehatan Mental Para Lanjut Usia Di Panti Wredha Harapan Ibu Semarang. UIN Walisongo Semarang.

Siradj, S. (2012). Pengantar Bimbingan Dan Konseling. Surabaya: Revka Petra Media.

Stuart, G. W., \& Sundeen, S. J. (2013). Buku Saku Ilmu Keperawatan jiwa (5th ed.). Jakarta: EGC.

Sugiyono. (2014). Metode Penelitian Pendidikan Pendekatan Kualitatif, Kuantitatif, dan $R \& D$. Bandung: Alfabeta.

Thohir, M. (2008). Konseling Rumah Sakit. Surabaya: IAIN Sunan Ampel Press.

Yosep, I. (2013). Keperawatan Jiwa (Edisi Revi.). Bandung: Refika Aditama.

Wawancara dengan Sinta Ristiani (Perawat Yayasan Jalma Sehat Kudus) pada 31 Agustus 2021, wawncara terlampir

Wawancara dengan Agus Salim (Pembimbing Agama Jalma Sehat Kudus) pada 10 September 2021, wawncara terlampir 